\title{
Medieval Biography between the Individual and the Collective
}

In a brief overview of medieval historiography penned by Herbert Grundmann historical writings seeking to present individuals are divided into two literary genres. Using a broad semantic term, Grundmann named the first group of texts vita, indicating only with an addition in the title that he had two types of texts in mind. Although he did not draw a clear line between the two, Grundmann placed legends intended for liturgical use side by side with "profane" biographies (Grundmann, 1987, 29). A similar distinction can be observed with Vollmann, who distinguished between hagiographical and non-hagiographical vitae (Vollmann, 1999², 1751-1752). Grundmann's and Vollman's loose divisions point to terminological fluidity, which stems from the medieval denomination of biographical texts. Vita, passio, legenda, historiae, translationes, miracula are merely a few terms signifying texts that are similar in terms of content. Historiography and literary history have sought to classify this vast body of texts according to type and systematize it, although this can be achieved merely to a certain extent. They thus draw upon literary-historical categories or designations that did not become fixed in modern languages until the 18th century (Berschin, 1986, 21-22). ${ }^{1}$

In terms of content, medieval biographical texts are very diverse. When narrating a story, their authors use different elements of style and literary approaches. It is often impossible to draw a clear and distinct line between different literary genres. Brunhölzl thus talks about "Nebeneinander und oftmals Ineinander des Biographischen und Hagiographischen" (Brunhölzl, 1999², 202). Biographies (vitae), legends, as well as hagiographies focus on a notable individual, attempting to provide the reader or listener with a vivid depiction of an individual, utilizing their own manner and literary approach. Establishing criteria for division of genres and classifying specific texts into a specific genre is predominately a literary and historical problem. If we seek to search for a reflection of a historical reality in a specific text, which is primarily regarded as one of historiography's main tasks, such qualification of texts is merely of secondary importance (Lotter, 1979, 320). Historiography is supposed to deal with as wide a range of texts as possible and, as pointed out by Berschin, be open to all forms and

1 Berschin classified medieval biographical texts into three large groups, distinguishing among legends, biographies, and hagiographies.

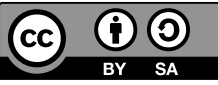

DOI:10.4312/ars.15.1.171-181 
contents that the Middle Ages invented to this end (Berschin, 1986, 21). The treatise at hand follows this principle. Despite terminological inconsistency - a conscious decision was made to put this aside - we are interested in all texts dealing with individuals and their activities, regardless of the texts' purpose or literary form. Primarily, the treatise seeks to provide a diachronic demonstration of the development of such texts in the Middle Ages and highlight individuals' role within them. In doing so, we shall gain an insight into the function and content-related value of biographical texts in the Middle Ages and their interpretative range.

Individuals' life stories were already depicted in ancient times. With Plutarch's Bior Пара́ $\lambda \lambda \eta \lambda \mathrm{o}$ and Suetonius' De vita Caesarum in the second century AD, biography as a separate literary genre reached its early zenith. However, Christian authors of late antiquity and of the early Middle Ages diverged from this ancient tradition, adopting merely the form and altering the genre's content significantly. Christian authors were no longer interested in rulers and influential individuals, instead they focused on martyrs and individuals whose actions and stances could serve as a model for the Christian way of life. Thus a series of hagiographical texts were produced, which with upwards of 10,000 units comprises the largest corpus within medieval biographies (Berschin, 1986, 3).

The authors' intent underwent a significant change, as did the focus of depiction. While Plutarch and Suetonius paid particular attention to character traits, attempting to use them to interpret individuals' decisions by means of which they impacted the course of historical events, hagiographers were interested mostly in individuals' positions and attitudes towards God. Hagiographies did not seek to familiarize the reader with historical facts. When in the early 6th century Eugippius narrated the story of saintly monk Severinus, who encouraged the inhabitants of Laureacum to defend themselves from barbarians, he did not want to convey a message to the reader that the Roman state was no longer capable of doing this and that the ecclesiastical organization already took over the function of the former civilian authorities. And when Eugippius enthusiastically explains how Severinus' prayers saved the crops from being destroyed by locust swarms and how the saint himself took care of a just division of food, he was not aware that he described a unique, late antiquity system of social support organized by subject of his text (Bratož, 1982, 116, 124). Eugippius' intent was hidden elsewhere. He wanted to hint to the reader that Severinus had all the main attributes of sainthood and that prayer and trusting in God is the best recipe for solving political and social problems. The information value of his biography does not lie in providing historical facts, but in demonstrating the power of God and his mercy.

Hagiographies were primarily used for liturgical veneration of saints, inspiring individuals and encouraging their internal growth (Grundmann, 1987, 29). These texts retained non-personal tendencies. They did not discuss the saints themselves, they 
dealt with God's actions performed through them (Derschka, 2014, 98 and 206). In his Liber in gloria martyrum Gregory of Tours summarized a general opinion that God himself fought and won through martyrs, while Bernard of Clairvaux associated sainthood with the loss of individual motivations, maintaining that a saint must become one with God's like a drop of water in a barrel of wine. The protagonists in hagiographies were thus not depicted as historical figures, but as harbingers of the invincibility of Christian values, the power of faith, and God's authority (Lotter, 1979, 307). Barring few exceptions, individual character traits disappeared, giving way to saints' typical features, which - according to their frequency - Hertling divided into 10 groups (Hertling, 1933, 265-266). Describing the human character was not one of medieval causae scribendi (Derschka, 2014, 100). The main message conveyed in hagiographies was that the saintly individual acted merely on behalf of God, was the conveyor of God's will, and, like prophets in the Old Testament, an intermediary between the mighty authority and the merciful judge on the one hand, and sinful people, impenitent in their hard-heartedness, on the other. Even though saints acted as main literary characters, hagiographical texts, in fact, talked about the relationship between God and his people, about the relationship between the absolute and the collective. The individual was placed in the background and the Christian community, which was addressed and encouraged by the saintly individual, stood at the forefront. Hagiography is not a narrative about an individual, is it a narrative about an ideal(ized) image of a community.

The few historical-political biographies which were produced in the early Middle Ages are difficult to distinguish from hagiographies. As regards their content, these are often merely lists of an individual's physical features and appearance. Unreflectingly, their actions are often assessed solely as either good or bad. Early medieval biography peaked with Einhard's vita of Charlemagne. Even though he highlights some of his individual abilities, Einhard regarded Charlemagne predominately as a ruler, not as an individual. He epitomizes a ruler's standardized image, which was influenced by Suetonius' biographies of Roman emperors (Derschka, 2014, 99).

Intended for depicting individuals' life stories, gestae, actions, is another literary genre noted by Grundmann. He argues this is a unique and specific medieval hagiographical genre modelled after Liber pontificalis. It includes biographical elements in the broader factual context (Grundmann 1987, 38-45; Sot, 1981, 13). The history of the monastery or the bishopric depicted consecutive actions performed by individual bishops or abbots. They were most often listed one after another in a monotonous manner like sculptures on a Gothic portal. However, similarly as in vitae, the informational value of gestae transcends depictions of individuals and their actions. For instance, in his narrative about Archbishop Adalbert in Gesta Hammaburgensis ecclesiae, Adam of Bremen included valuable data on inhabitants of the continent's 
extreme north. In doing so, he was the first to familiarize Central European readers with peoples from Iceland, Greenland, and Scandinavia and all the way to the Baltic. However, the purpose of his writing was not an ethnological depiction of these peoples and their lands. Much to the contrary, he simply wanted to demonstrate clearly how far the Archbishopric of Hamburg's claims on ecclesiastical jurisdiction reached (Grundmann, 1987, 42). The main role in the narrative was thus actually played by the archbishopric and not by an archbishop himself. An individual was merely an instrument of the institution and acting on its behalf.

How individuals' actions were evaluated through the prism of the collective or an institution in the late 10th and early 11 th centuries is nicely demonstrated by a few sources that mention the Holy Roman Emperor Henry II. Henry, who ruled in the first decades of the 11th century, was along with his spouse Cunigunde the only German medieval king who was officially recognized as saint, whereby the Bishopric of Bamberg played the key part. Naturally, the bishopric's efforts were not a coincidence. It was Henry himself who actually founded the bishopric in 1008 and is buried alongside his spouse Cunigunde in Bamberg Cathedral. It is thus not surprising that a text, which is thought to have been written by a certain deacon Adalbert as early as in the mid-12th century, was produced in Bamberg that praised Henry's actions and depicted his life in an obvious hagiographical manner. However, at the same time texts that were considerably more critical of Henry and cast a shadow on his reputation were also produced. Bruno of Querfurt criticized Henry's alliance with the pagan Lutici against the Christian Duke of Poland, wondering whether it was acceptable to persecute a Christian people and have friendly relations with pagans. Similarly, a presumable injustice done by the Emperor to his acquaintances prompted Thietmar of Merseburg to voice harsh words, maintaining that even he who was anointed by the Lord could be a sinner (Weinfurter, 2002, 204-208). This rapidly changing perspective is mirrored best in the Annals of Quedlinburg. In the first years of Henry's reign, when Quedlinburg lost its position as one of the most important of his residences, the annals were highly critical of Henry's manner of ruling. However, in 1014, when Henry entrusted Abbess Adeleide with the administration of convents in nearby Gernrode and Vreden, along with her original convent, the tone of the annals changed quickly and became almost panegyrical after 1021, when the Emperor visited the convent and endowed it richly (Althoff, 1991, 143-144). Henry's example indicates that in the 11th century individuals' character and personality traits were still not subject to reflection. A man's actions and decisions, let alone his ideas and visions, were not a yardstick for evaluating him. Even a ruler and saint such as Henry II was assessed merely through a prism of the welfare of a concrete collective, and only a few authors were capable of setting the community's boundary broader than the dynasty or institution to which they belonged. 
However, with the arrival of profound social and economic changes beginning in the mid-11th century and taking off properly in the 12th and 13th centuries emerged a different understanding of the individual and, consequently, texts with biographical content. The philosophical discourse that accompanied a dispute on the nature of universals, in particular, prompted the formation of new concepts that gradually led to the emergence of a transformed relationship between the society and its individual members. Initially limited to a narrow circle of the social elite, people were perceived gradually as individuals and only later as members of a broader community (Dinzelbach, 2008, 29). This was not so much an instance of rediscovering a term as a deep change of the existing paradigm. It was a process during which people were becoming aware of their own individuality and that of their fellow human beings. In the 12th and 13th centuries they began to articulate this idea (Derschka, 2014, 11).

With new principles marked by individualization, the process made a deep cut into the existing social patterns, and the realm of faith was no exception. Twelfth-century mystics laid the foundations of the new perception of Christ. The image of the Son of God as a superior and remote ruler was gradually transformed into that of a close, personal friend, who pays attention to each and every believer. The collective was no longer a subject of mystical religious experience. It was instead the individual whose soul becomes one with God (Derschka, 2014, 31-33). A similar change occurred in the concepts of several other religious categories. A collective salvation within the universal Church was in the 12th century replaced by the notion of the Last Judgement, with which each individual will be faced after their death and judged for their actions on Earth. The concept of purgatory and a new understanding of sin were also established, which was ultimately manifested in 1215 with a new normative regulation of sacraments. Similar changes can be observed in all areas of man's dwelling, so to speak. Derschka referred to them as "Orte der Individualität", places of individuality, pointing out 11 realms that reflect the aforementioned social changes (Derschka, 2014, 29ff.).

Social changes were also reflected in relation to biographical texts. In the mid12th century Otto of Freising, for example, penned Gesta Friderici I, which almost slipped into oblivion, unlike his World Chronicle. Hagiographies also acquired more and more individual traits (Stark, 1996, 704ff.). Older uncritical vitae could obviously no longer satisfy the changed demands and taste of the period. Thomas de Celano thus wrote the first biography of Francis of Assisi around 1230 and included stories from his childhood and youth in his text. Berschin labelled Thomas of Celano's biography as an example of the emancipation of medieval hagiographies from the tradition of late antiquity (Berschin, 2004, 90-91).

Along with vitae and gestae, one should also make at least a brief mention of autobiographies. Autobiography was not a separate literary genre in antiquity; however, medieval authors could build upon two traditions that occurred in that time. The first 
group is represented by third-person accounts, which were modelled after Caesar's Gallic Wars, where the author seeks to justify his actions; the second group is represented by texts resembling Marcus Aurelius' contemplations, which did not focus on the author's actions, but rather on his desire for giving thought to his inner life (Derschka, 2014, 106). With Augustine's Confessiones, which were produced in the late 4th century, one of the most influential Christian thinkers created a masterpiece of reflective introspection. However, it was not until around 1100 that his text was perceived as an autobiography. Before that, Augustine's account was regarded as a story of the saint's conversion, rather than a reflection on his own feelings, thoughts, and actions (Derschka, 2014, 106). Augustine is thus by no means to be regarded as an originator of medieval autobiography (Lehmann, 1998², 290).

There are just a few early medieval autobiographical texts that mostly focus on describing concrete actions or addressing individuals' spiritual experience, and no autobiographical text of this kind depicts an individual's life from their birth to death (Lehmann, 1998², 285-289, Derschka, 2014, 107). It was only the social changes that occurred in the 12th century that gave new impetus to this literary genre, which Derschka refers to as a qualitative breakthrough (Derschka, 2014, 107) and Berschin an autobiographical wave (Berschin, 2001, 350). Two important autobiographical texts were produced in the 12th century. Guibert, Abbot of the Benedictine monastery Nogent-sous-Coucy in Picardy, northern France, recounted his life in De vita sua sive Monodiae and followed Augustine's example by including his childhood. A few decades later Peter Abelard wrote his view on his life in Historia calamitatum mearum, where he depicts himself as a tragic victim of his own vanity and his passionate dedication to the truth. In the early 13th century, Gerald of Wales joined Giubert and Abelard with a text that he confidently entitled De rebus a se gestis. Evaluating such texts and their contribution to "discovering an individual" has been marked by differences of opinion among experts. Wilhelm Kölmel sees them as an indicator of significant social changes (Kölmel, 1996, 680-682), while Aaron Gurevich maintains that medieval autobiographies document the incapacity of describing one's own unique inner world because the authors make use of a wide range of traditional topoi, whereby the author's real, true self is elusive (Gurjewitsch, 1994, 194-195, 242). However, despite all scepticism that can be expressed in each of these examples, it holds true that from the 12th century onwards at the latest people felt a more intensive need to portray their own fate and elements of their inner life (Derschka, 2014, 113).

The changing perception of an individual gave new impetus to biographical texts in the late Middle Ages. The quantity of such texts increased considerably, the circle of their authors expanded and was no longer restricted to the clergy, and their target audience was differentiated as well. Latin, the Church's and scholar's universal language intended for liturgy and scientific discussions, gave way to vernacular languages that 
were understood by a broader swathe of readers and in which it was easier to disclose one's deepest sentiments. The texts' form became more diverse as well (Müller, 19982, 315-320). Different biographical and autobiographical elements can be seen also in love poetry of the High Middle Ages (Minnesang, Troubadours, Trouvères), where it is often unclear whether this is fiction or a portrayal of someone's actual experiences. Texts by many German mystics include biographical elements, e.g. those by Mechthild of Magdeburg or Henry Suso that reached a relatively broad readership in the late Middle Ages. Depictions of lives of noblemen or knights were popular, their versified form was often that of Preisrede or Totenklage, i.e. written in praise of or lament for the dead. Biographical texts could be intended for political propaganda, e.g. memoirs by Helene Kottanner, who saved the legitimacy of Ladislaus the Posthumous by stealing the Hungarian crown. From the late 14th century onwards, burghers began to write their experiences in the form of family chronicles, e.g. Ulman Stomer, a citizen of Nuremberg, and his Püchel von mein geslecht und von abentewr or Burkhard Zink, who concluded the chronicle of the city of Augsburg with an account of his own life. ${ }^{2}$ Many biographical elements are also seen in reports written by travellers and missionaries, which were popular among the readership of the late Middle Ages. Charles IV's autobiography, entitled Vita Caroli IV imperatoris Romani ab eo ipso conscripta, which ends where a ruler's autobiography should actually begin, namely with him obtaining the German crown and the beginning of his involvement in historical events (Lehmann, 1998², 290-294; Grundmann, 1987, 38), stands out among autobiographical texts of this era. The end of the 15th century saw the publication of Theuerdank and Weißkunig, where Maximilian I had his life praised in a knightly manner and which appears to be the final reflex of the waning Middle Ages (Grundmann, 1987, 38).

The 14th century saw the emergence of biographical texts that built upon entirely new starting points and have little in common with the medieval tradition. It was not long before early humanists began to emulate ancient examples and produced extensive collections of biographies. In the mid-14th century Petrarch penned De viris illustribus and performed several redactions, while Giovanni Boccaccio revised his Trattatello in laude di Dante several times. He expanded his biographical production with the Latin collections De casibus virorum and De mulieribus claris at a later point. Similarly, Giannozzo Manetti wrote about Dante, Petrarch, and Boccaccio in the early 15th century, and a few decades later Enea Silvio Piccolomini compiled De viris illustribus in Latin. However, a developmental trajectory can also be observed in early humanist authors. Namely, if Petrarch and Boccaccio focused on biblical or ancient figures in their texts and Manetti wrote about deceased humanists, Piccolomini had no qualms about focusing on his contemporaries, both from the ranks of rulers or those who

2 Grundmann classifies such texts as urban chronicle writing, not as biographies. Cf. Grundmann, 1987, 45-48. 
shared his ideas. He included Barbara of Celje, widow of the Emperor and King Sigismund, among figures worthy of having a biography. However, Piccolomini was also a man of his time. The features that he used to portray specific people were heavily contingent upon his attitude towards them, and this attitude, in turn, was conditioned by political circumstances. The Counts of Celje are a wonderful example of his partiality. When discussing the House of Celje, his early texts display a favourable diction, which was considerably sharper at a later stage. Following Ulrich's collaboration with Austrian nobility in the League of Mailberg in 1452, Piccolomini became a merciless judge and his words razor-sharp. He reproached Barbara for lust and moral corruption and depicted Ulrich and Frederick as unpredictable opportunists, who were only capable of following their own political interests and satisfying their physical desires (Mlinar, 2005, 70sl). However, the credibility of Piccolomini's assessment is highly questionable, since his work is inspired by ancient models. Having experienced the Austrian nobility's alliance against Frederick III as the ruler's chancellor, Piccolomini viewed the League of Mailberg as a Catilinarian conspiracy against the Roman republic. Consequently, specific persons from the League bore striking resemblance with Sallust's depictions of conspirators. Ulrich of Celje was thus given Catiline's features, while Barbara took over the role of Sempronia (Wagendorfer, 2003, 149-158). Therefore, Piccolomini's depictions of the Counts of Celje do not disclose their personality traits, but rather demonstrate the author's fondness for ancient literary models, particularly Sallust. In this regard Piccolomini was no exception, as a similar pattern of emulating character traits can also be observed in Valori or Machiavelli (Burke, 1999, 66). Influenced by Plutarch's Parallel Lives, which the Western world took up once again in the mid-15th century through translations, younger humanist authors began to pay more attention to trivial things, which in Plutarch's opinion often reveal more about a person's character than bloody conflicts, as he argued in the introduction to his biography of Alexander the Great. With the new approach, which did not take root until the 16th century, the road to biography as understood today was finally paved.

The Renaissance of the 12th century presents itself as an important watershed in the development of medieval biography writing. The changed attitude towards the individual, who gradually broke loose from the framework of the collective and acquired individual traits, was also reflected in texts. However, in practical terms not much changed as far as historians are concerned, and they still face great difficulties when attempting to gain insight into an individual's inner life, feelings, and thinking. An individual's inner organization, whose core makes them different from others, remains concealed. The reason lies in the quantity and structure of sources and, consequently, in methodological difficulties (Derschka, 2014, 201). Le Goff, for instance, maintains in his contemplation of biographies that it is extraordinarily difficult to find enough materials to write anybody's biography in the period before the 14th century, barring 
the most important figures that fall into two categories, kings and saints. However, at the same time he points out that it is still appealing to describe individuals, summarizing the words of his colleague Bernard Guenée, which describe the attraction that biographies hold for historians in the most beautiful way (Le Goff, 1989, 394 and 405). Guenée argues that the structural approach illuminates the past with wonderful coherency, but this coherency simplifies history. Biographies, on the other hand, enable an insight into history's dominant complexity. A biography enables us to focus more on coincidences, events, and chronological sequence, and gives the historian an overall feel of the period in which people lived.

\section{References}

Aertsen, J. A. et al. (ed.), Individuum und Individualität im Mittelalter. Miscellanea Medievalia 24, Berlin, New York 1996.

Aertsen, J. A., Einleitung: Die Entdeckung des Individuums, in: Individuum und Individualität im Mittelalter (ed. Jan A. Aertsen et al.). Miscellanea Medievalia 24, Berlin, New York 1996, pp. IX-XVI.

Althoff, G., Gandersheim und Quedlinburg. Ottonische Frauenklöster als Herrschafts- und Überlieferungszentren, in: Frühmittelalterliche Studien 25, 1991, pp. 123-144.

Berschin, W., Biographie und Epochenstil im lateinischen Mittelalter. Vol. I: Von der Passio Perpetuae zu den Dialogi Gregors des Großen. Quellen und Untersuchungen zur lateinischen Philologie des Mittelalters VIII, Stuttgart 1986.

Berschin, W., Biographie und Epochenstil im lateinischen Mittelalter. Vol. IV/2: Ottonische Biographie. Das hohe Mittelalter 920-1220 n. Chr. Zweiter Halbband 1070-1220 n. Chr. Quellen und Untersuchungen zur lateinischen Philologie des Mittelalters XII/2, Stuttgart 2001.

Berschin, W., Biographie und Epochenstil im lateinischen Mittelalter. Vol. V: Kleine Topik und Hermeneutik der mittellateinischen Biographie. Quellen und Untersuchungen zur lateinischen Philologie des Mittelalters XV, Stuttgart 2004.

Bratož, R., Evgipij, Življenje svetega Severina, Ljubljana 1982.

Brunhölzl, F., entry: Biographie. II. Mittellateinische Literatur, Lexikon des Mittelalters II, Stuttgart 1983, pp. 200-203.

Burke, P., Individuality and Biography in the Renaissance, in: Die Renaissance und die Entdeckung des Individuums in der Kunst. Die Renaissance als erste Aufklärung II (ed. Rudolph E.), Tübingen 1998.

Derschka, H., Individuum und Persönlichkeit im Hochmittelalter, Stuttgart 2014.

Dinzelbach, P. (ed.), Europäische Mentalitätsgeschichte, Stuttgart 2008.

Grundmann, H., Geschichtsschreibung im Mittelalter. Gattungen - Epochen - Eigenart, Göttingen $1987^{4}$.

Gurjevitsch, A., Geburt des Individuums, translated by Erhard Glier, München 1994.

Hertling, L., Der mittelalterliche Heiligentypus nach Tugendkatalogen. Zeitschrift für Aszese und Mystik 8, 1933, pp. 260-268.

Kölmel, W., Autobiographien der Frühzeit, in: Individuum und Individualität im Mittelalter (ed. Aertsen J. A et al.). Miscellanea Medievalia 24, Berlin, New York 1996, pp. 667-682. 
Le Goff, J., After Annales. The Life as History, Times Literary Supplement, no. 4, 489 (April 1420), pp. 394 and 405. (Slovene translation Le Goff, J., Življenje kot zgodovina. Preporod biografije, Naši razgledi 28, No. 21 (10 November 1989), pp. 639-640.

Lehmann, P., Autobiographien des Lateinischen Mittelalters, in: Die Autobiographie. Zu Form und Geschichte einer literarischen Gattung (ed. Niggl G.), Darmstadt 1998², pp. 283-296.

Lotter, F., Methodisches zur Gewinnung historischer Erkenntnisse aus hagiographischen Quellen, Historische Zeitschrift 229/2 1979, pp. 298-356.

Mlinar, J., Podoba Celjskih grofov v narativnih virih, Ljubljana 2005.

Müller, U., Thesen zu einer Geschichte der Autobiographie im deutschen Mittelalter, in: Die Autobiographie. Zu Form und Geschichte einer literarischen Gattung (ed. Niggl G.), Darmstadt 19982, pp. 297-320.

Philippart, G., Les légendiers latins et autres manuscrits hagiographiques. Typologie des sources du moyen âge occidental 24-25, Turnhout 1977.

Sot, M., Gesta episcoporum, Gesta abbatorum. Typologie des sources du moyen âge occidental 37, Turnhout 1981.

Stark, B., Elisabeth von Thüringen: Die Entdeckung individueller Züge in der Biographie einer Heiligen, in: Individuum und Individualität im Mittelalter. (ed. Aertsen J. A et al.). Miscellanea Medievalia 24, Berlin, New York 1996, pp. 704-719.

Vollmann, B. K., entry: Vita, Lexikon des Mittelalters VIII, Stuttgart 1997, pp. 1751-1752.

Wagendorfer, M., Studien zur Historia Australis des Aeneas Silvius de Piccolominibus. Mitteilungen des Instituts für Österreichische Geschichtsforschung, Ergänzungsband 43. Wien, München 2003.

Weinfurter, S., Heinrich II. (1002-1024). Herrscher am Ende der Zeiten, Regensburg 1999³.

Janez Mlinar

\section{Medieval Biography between the Individual and the Collective}

Keywords: biography, hagiography, historiography, Middle Age

The treatise focuses on a diachronic demonstration of the development of biographical texts in the Middle Ages, pointing to individuals' role within these texts. This allows for a definition of content-related value of medieval biographies and their interpretative range.

Medieval biographical texts built upon ancient materials only in part. In the early Middle Ages hagiographies and, to some extent, gestae gained prominence; however, they focused on the collective, not the individual. Collective values and goals were thus projected on to a literary character. The so-called twelfth-century Renaissance presents itself as a key moment in the shift of paradigm. Broader social changes also brought about a new perception of the individual. Having previously been reduced to types, individuals began to acquire particular traits. A shift in the perception of an individual gave new impetus to biographical texts in the late Middle Ages. The quantity of such texts increased considerably, the circle of their authors expanded and was no longer restricted to the clergy, and their target audience was differentiated as well. Gradually, vernacular languages took root and the forms of texts became more diverse. 
Nevertheless, the internal structure of a medieval individual remains concealed due to the quantity and structure of sources and, consequently, methodological issues. On the other hand, it is for these reasons that medieval biographies provide an insight into history's dominant complexity.

Janez Mlinar

\section{Srednjeveška biografija med individualnim in kolektivnim}

Ključne besede: biografija, hagiografija, zgodovinopisje, srednji vek

Razprava se osredotoča na diahroni prikaz razvoja biografskih zapisov v srednjem veku in skuša opozoriti na vlogo posameznika $v$ njih. Na ta način je mogoče opredeliti vsebinsko vrednost srednjeveških biografskih zapisov in njihov interpretativni domet.

Srednjeveški biografski zapisi so se le deloma naslanjali na antična izhodišča. V zgodnjem srednjem veku so se uveljavile zlasti hagiografije in deloma gestae, ki pa so se osredotočale na kolektiv in ne na posameznika. V literarno osebo so bile zgolj projicirane kolektivne vrednote in cilji. Kot ključni moment pri menjavi paradigme se kaže t. i. renesansa 12. stoletja. Širše družbene spremembe so prinesle tudi drugačno dojemanje posameznika. Iz tipiziranih upodobitev so posamezniki začeli pridobivati individualizirane poteze. Spremenjeno dojemanje individuuma je v poznem srednjem veku biografskim besedilom dalo nov zagon. Količina tovrstnih besedil se je močno povečala, razširil se je krog avtorjev, ki ni bil več omejen zgolj na duhovščino, diferencirala pa se je tudi ciljna publika. Postopoma so se uveljavili vernakularni jeziki, raznovrstnejše pa so postale neformalne oblike.

Toda kljub temu ostaja notranja organizacija posameznega srednjeveškega individuuma prikrita. Razlog je v količini in strukturi virov ter posledično v metodoloških težavah. Po drugi strani pa nam ravno zato srednjeveške biografije omogočajo vpogled v prevladujočo kompleksnost zgodovine.

\section{About the author}

Janez Mlinar is an associate professor of Slovene and general history of the Middle Ages at the Department of History of the Faculty of Arts, University of Ljubljana. In his scientific research work, he focuses mainly on medieval historiography, urban history and the history of the Julian Alps.

\section{O avtorju}

Janez Mlinar je izredni profesor za slovensko in občo zgodovino srednjega veka na Oddelku za zgodovino Filozofske fakultete Univerze v Ljubljani. V svojem znanstveno-raziskovalnem delu se posveča zlasti srednjeveškemu zgodovinopisju, urbani zgodovini in zgodovini prostora Julijskih Alp. 